Martyna Walas*

\title{
Polish Legal Bibliography of Environmental Law
} For period: $1^{\text {st }}$ October $2014-31^{\text {st }}$ August 2015 (on the basis of Polish Legal Bibliography in Państwo i Prawo and Bibliography of Polish Academy of Science)

\author{
Polska Bibliografia Prawnicza \\ z zakresu ochrony środowiska \\ Za okres: 1 października 2014-31 sierpnia 2015 \\ (na podstawie Polskiej Bibliografii Prawniczej \\ w Państwie i Prawie oraz Bibliografii Polskiej \\ Akademii Nauk)
}

Bar M., Wydanie decyzji o środowiskowych uwarunkowaniach dla zrealizowanego przedsięruzięcia, Prawo i Środowisko 2015, No 2.

Ph.D. Candidate at the Chair of Environmental Protection Law, Faculty of Law and Administration, Nicolaus Copernicus University in Torun. 
Bar M., Górski M., Jendrośka J., Jerzmański J., Pchałek M., Urban S., Radecki W., Prawo ochrony środowiska. Komentarz, Warszawa 2014.

BarM.,JendrośkaJ., Kragstron w postępowaniach wsprawiepozwoleñ zintegrowanych a prawo UE i międzynarodowe, Prawo i Środowisko 2014, No 3.

Barczak A., Ewolucja zasady bliskości w zakresie gospodarowania odpadami w prawie polskim na tle prawa unijnego, in: Obywatel - państwo - spoteczność międzynarodowa, eds. E. Cała-Wacinkiewicz, K. Flaga-Gieruszyńska, D. Wacinkiewicz, Warszawa 2014.

Barczak A., Pozycja prawna wójta w ochronie środowiska, in: Pozycja ustrojowa organów wykonawczych jednostek samorządu terytorialnego, eds. K. MałysaSulińska, M. Stec, Warszawa 2014.

Barczak A., Górski M., Dostęp do informacji o środowisku jako publiczne prawo podmiotowe i grwarancje jego ochrony, in: Dziesięć lat polskich doświadczeń w Unii Europejskiej. Problemy prawnoadministracyjne, vol. II, ed. J. Sługocki, Szczecin 2015.

Barczak A., Kowalewska E., Zadania samorzqdu terytorialnego w ochronie srodowiska. Aspekty materialne i finansowe, Warszawa 2015.

Baran M., Glosa do wyroku Naczelnego Sadu Administracyjnego z dnia 22 grudnia 2011 r., II OSK 1729/10, Przegląd Prawa Ochrony Środowiska 2015, No 1.

Bieluk J., Regulacja prawna integrowanej ochrony roślin, Studia Iuridica Agraria 2014, Vol. 12.

Bieluk J., Lobos-Kotowska D., Ustawa o ochronie gruntów rolnych i leśnych. Komentarz, Warszawa 2015.

Błachnio M., Nowe wyzwanie dla mediacji - sprawy z zakresu ochrony środowiska, in: Mediacja: nowa przestrzeń zarzqdzania konfliktem: wyzwania, strategie, rozwiqzania, eds. S. Morgała, E. Stopyra, Warszawa 2014.

Branecki T., Organizacja i funkcjonowanie szwajcarskiej administracji federalnej

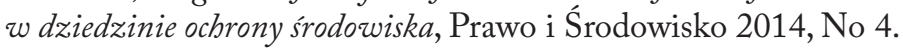

Brodawka M., The analysis of the implementation of the environmental impact assessment of projects in the Polish legal system, Polish Yearbook of Environmental Law No 4 (2014).

Brynczak B., Kenig-Witkowska M. M., Przygoda K., Rybski R., Stoczkiewicz M. (ed.), Gaz tupkowy w Polsce. Aspekty prawno-środowiskowe, Warszawa 2014.

Bryndziak S., Opodatkowanie jako instrument polityki ochrony środowiska, Studia Prawno-Ekonomiczne 2014, No 93.

Budziński Ł., Mostowska A. (ed.), Wilczyńska J., Ustawa o odpadach. Komentarz, Warszawa 2014.

Bugajska A. Kulig A., Prawodawstwo w ochronie środowiska z elementami ocen oddziaty wania na środowisko. Materiaty dydaktyczne do wykładu, Warszawa 2014. 


\section{Polish Legal Bibliography of Environmental Law...}

Burchart A., Poszewiecki A., Szymańska U., Rola samorzqdu gminnego i jego obywateli w zaperwnieniu bezpieczeństwa ekologicznego zasobów wodnych, Civitas et Lex 2014, No 1.

Cheda J., Konstytucyjne podstawy bezpieczeństwa ekologicznego w Polsce, in: Prawne i gospodarcze podstawy bezpieczeństwa, eds. S. Kamosiński, T. Kuczur, J. Laskowska, Bydgoszcz 2015.

Chmielewski J., Lasy ochronne. Przyczynek do rozważań nad administracyjnoprawna problematyka lasów szczególnie chronionych, Przegląd Prawa Ochrony Środowiska 2014, No 4.

Chojnacka I., Konieczne zmiany ustawy o ochronie przyrody po wyroku Trybunatu Konstytucyjnego o sygn. SK 6/12, Przegląd Legislacyjny 2015, No 2.

Ciechanowicz-McLean J., Globalizacja $i$ europeizacja w publicznym prawie gospodarczym i w prawie ochrony środowiska, in: Dziesięć lat polskich doświadczeń w Unii Europejskiej. Problemy prawnoadministracyjne, vol. I, ed. J. Sługocki, Szczecin 2015.

Ciechanowicz-McLean J., Prawo ochrony i zarządzania środowiskiem, Warszawa 2015.

Ciechanowicz-McLean J., Ramowa dyrektywa wodna a ochrona środowiska morskiego, Prawo Morskie 2013, No 29.

Ciechanowicz-McLean J., Recenzja: K. Kępka, Prawnomiędzynarodowe aspekty zmian klimatycznych (Warszawa 2013), Prawo i Środowisko 2014, No 2.

Ciechanowicz-McLean J., Nyka M., Podstawowe zatożenia środowiskowej gospodarki morskiej, Prawo morskie 2014, No 30.

Ciesielska A., Jasman K., Wybrane aspekty przeniesienia pozwolenia wodnoprawnego, Przegląd Prawa Ochrony Środowiska 2014, No 3.

Czajkowska-Matsiuk K., Kompensacja przyrodnicza realizowana w toku procesu inwestycyjnego, Prawo i Środowisko 2014, No 2.

Czajkowska-Matsiuk K., Ograniczenie korzystania z nieruchomości w związku z wymogami ochrony środowiska, Prawo i Środowisko 2015, No 1.

Czajkowska-Matosiuk K., Plany gospodarki odpadami, Prawo i Środowisko 2014, No 2.

Czajkowska-Matosiuk K., Realizacja inwestycji budowlanych a utrudnienia wynikajace z prawa ochrony przyrody i prawa wodnego, Prawo i Środowisko 2014, No 3.

Czarnow S., Bezprawne pozyskiwanie zwierzyny a gospodarka towiecka, Kontrola Państwowa 2015, No 2.

Czech E. K., Kwestia istnienia jednoznaczności i spójności terminologicznej norm, w oparciu o które chronione sq lasy - studium wybranych ustaw, Białostockie Studia Prawnicze 2015, No 18. 
Czech M., Objective liability for removal of trees or shrubs without the required permit in the light of recent judicature views, Polish Yearbook of Environmental Law No 4 (2014).

Czekała W., Lewicki A., Janczak D., Problemy zasad klasyfkacji odpadów organicznych, Przegląd Prawa Ochrony Środowiska 2014, No 3.

Danecka D., Olejarczyk E., Profesor Wojciech Radecki Doktorem Honoris Causa Uniwersytetu Ślaskiego, Przegląd Prawa Ochrony Środowiska 2014, No 3.

Danecka D., Radecki W., Glosa do decyzji Generalnego Dyrektora Ochrony Środowiska z 8 IV 2014, DPZ-WG, Prawo i Srodowisko 2014, No 4.

Danecka D., Radecki W., Prawna ochrona zwierzqt w Republice Czeskiej w porównaniu z prawem polskim, Przegląd Prawa Ochrony Środowiska 2014, No 3.

Danecka D., Radecki W., Zasada „zanieczyszczajacy ptaci” w czeskim prawie środowiska w porównaniu z prawem polskim, Przegląd Prawa Ochrony Środowiska 2015, No 1.

Daniel P., Glosa do wyroku Wojewódzkiego Sadu Administracyjnego w Gliwicach z dnia 17 czerwca 2014 r., sygn. akt II SA/Gl 55/14, Przegląd Prawa Ochrony Środowiska 2014, No 4.

Daniel P., O możliwości wstrzymania wykonania decyzji o środowiskowych uwarunkowaniach zgody na realizacje przedsięwzięcia w postępowaniu sądowo administracyjnym, Przegląd Prawa Ochrony Środowiska 2014, № 2.

Daniel P., Przestanki wytaczajace wymierzenie kary administracyjnej z tytutu usunięcia drzew lub krzewów bez wymaganego zezwolenia, Przegląd Prawa Ochrony Środowiska 2014, No 2.

Dobrostan zwierzat w ogrodach zoologicznych a standardy prawne UE. Wersja polskojezyczna, eds. T. Gardocka, A. Gruszczyńska, R. Maślak, A. Sergiel, Warszawa 2014.

Dołęgowska E., Ograniczanie wtasności ze względu na ochronęśrodowiska w kontekście zasady zrórwnoważonego rozwoju, Białostockie Studia Prawnicze 2015, No 18.

Draniewicz B., Kary pieniężne w ustawie o ochronie przyrody, Prawo i Środowisko 2015, No 2.

Draniewicz B., Kary pieniężne za usuwanie drzeww i krzewów - po wyroku Trybunatu Konstytucyjnego, Prawo i Środowisko 2014, No 4.

Draniewicz B., Eagodzenie odpowiedzialności z tytutu deliktów administracyjnych orzecznictwo, Prawo i Środowisko 2014, No 2.

Draniewicz B., Przedawnienie wymierzania kar pieniężnych, Prawo i Środowisko 2015, No 1.

Draniewicz B., Zakres obecnej i planowanej ustawy o ZSEE, Prawo i Środowisko 2014, No 4. 
Dropińska-Bysiek J., Decyzja o środowiskowych uwarunkowaniach bez uprzedniego przeprowadzenia oceny oddziatywania na środowisko wydawana w procesie budowlanym, Casus 2014, No 72.

Dziatalnośc gospodarcza na obszarach chronionych, eds. R. Biskup, M. Pyter, M. Rudnicki, J. Trzewik., Lublin 2014.

Dziki U., Prawo cztowieka do środowiska naturalnego - wybrane aspekty prawne i pozaprawne, in: Prawa człowieka: wspótczesne zjawiska, wyzwania, zagrożenia, vol. 1, ed. A. Kalisz, Sosnowiec 2015.

Europejskiwymiarbezpieczeństwaenergetycznegoaocbrona środowiska. Bezpieczeństwo, edukacja, gospodarka, ochrona środowiska, polityka, prawo, technologie, eds. P. Kwiatkiewicz, R. Szczerbowski, Poznań 2014.

Federczyk W., Fogel A., Kosieradzka-Federczyk A., Prawo ochrony środowiska w procesie inwestycyjno-budowalnym, Warszawa 2015.

Flick G. M., Z prawnej problematyki ochrony lasów we Wtoszech, Przegląd Prawa Rolnego 2014, No 1.

Fogel A., Uwarunkowania prawnoustrojowe ochrony i ksztattowania krajobrazu, Samorząd Terytorialny 2014, No 12.

Gesek N. K., Konstytucyjnoprawna problematyka procedury tworzenia obwodów towieckich, Przegląd Prawa Ochrony Środowiska 2014, No 3.

Gogojewicz P., Nowe prawo towieckie, Prawo i Środowisko 2015, No 2.

Goździewicz-Biechońska J., Formy ochrony krajobrazu wiejskiego w świetle ustawy o ochronie przyrody, Przegląd Prawa Rolnego 2014, No 2.

Goździewicz-Biechońska J., $Z$ prawnej problematyki ochrony krajobrazu na obszarach wiejskich, Przegląd Prawa Rolnego 2014, No 1.

Górski M., Decyzje administracyjne w zakresie międzynarodowego obrotu odpadami jako przyktad bezpośredniego wspótdziatania norm prawa unijnego i wewnętrznego, in: Obywatel-państwo-spoteczność międzynarodowa, eds. E. Cała-Wacinkiewicz, K. Flaga-Gieruszyńska, D. Wacinkiewicz, Warszawa 2014.

Górski M., Barczak A., Prawo dostępu do informacji o środowisku i jego ochronie jako element realizacji zasady demokratycznego państwa prawnego, Acta Iuris Stetinensis 2014, No 7.

Gronowska B., O prawie do środowiska w systemie Europejskiej Konwencji Praw Cztowieka - refleksje na tle najnowszego orzecznictwa strasburskiego, Przegląd Prawa Ochrony Środowiska 2014, No 1.

Gruszecki K., Glosa do wyroku Naczelnego Sadu Administracyjnego z 15 I 2013, II OSK 1676/11, Zeszyty Naukowe Sądownictwa Administracyjnego 2014, No 5.

Gruszecki K., Glosa do wyroku Wojewódzkiego Sądu Administracyjnego we Wroctawiu z 23.04.2014 r. II Sa/Wr 48/14, Gdańskie Studia Prawnicze. Przegląd Orzecznictwa 2015, No 1. 


\section{Martyna Walas}

Gruszecki K., Wspótdziatanie pomiędzy organami administracji w procesie wydawania decyzji określającej warunki realizacji przedsięwzięcia, Casus 2014, No 73.

Gutkowski B., Aktualne przepisy w ochronie środowiska, Koszalin 2014.

Haładyj A., Legal Grounds and Prospects for Public Participation in Climate Protection Projects - Polish Experience, Polish Yearbook of Environmental Law No 4 (2014).

Haładyj A., Pogranicza materialnego prawa administracyjnego na przykładzie prawa ochrony środowiska, in: Dziesięć lat polskich doświadczeń w Unii Europejskiej. Problemy prawnoadministracyjne, vol. I, ed. J. Sługocki, Szczecin 2015.

Haładyj A., Udziat spoteczeństwa w strategicznej ocenie oddziatywania na środowisko jako instytucja prawa ochrony środowiska, Lublin 2015.

Haładyj A., Trzewik J., Pojęcie strategicznych zasobów naturalnych-uwagi krytyczne, Przegląd Prawa Ochrony Środowiska 2014, No 1.

Handzel-Urbańczyk K., The right of access to information on the environment and its protection - a case study, in: Obywatel-państwo-spotecznośc międzynarodowa, eds. E. Cała-Wacinkiewicz, K. Flaga-Gieruszyńska, D. Wacinkiewicz, Warszawa 2014.

Ignatowicz G., Realizacja zasady zrównoważonego rozwoju w polityce ekologicznej Polski po konferencjach w Rio de Janeiro w 1992 oraz 2012 roku, Białostockie Studia Prawnicze 2015, No 18.

Ignatowicz G., Dołęgowska E., Renewable energy sources in the light of regulations of the Polish law and the European Union Law, Polish Yearbook of Environmental Law No 4 (2014).

Inwestycje infrastrukturalne $i$ ochrona środowiska w prawie energetycznym, eds. K. Ziemski, P. Lissoń, Poznań 2014.

Jankowski B., Oddziatywanie Wspólnej Polityki Rolnej na ochronęśrodowiska, Studia Iuridica Agraria 2012, Vol. 12.

Jaś-Nowopolska M., Wybrane dziatania prowadzace do ograniczenia emisji spalin z samochodów osobowych, Przegląd Prawa Ochrony Środowiska 2014, No 1.

Jaworowicz-Rudolf A., Odpowiedzialność z tytutu zapobiegania i naprawiania szkód w środowisku, Acta Universitatis Lodziensis. Folia Iuridica 2015, No 74.

Jaworowicz-Rudolf A., Środowisko jako dobro chronione, in: Dobra chronione w prawie administracyjnym, ed. Z. Duniewska, Łódź 2014.

Jaworowicz-Rudolf A., Zarys prawnej reglamentacji usuwania drzew i krzewów de lege lata oraz w siwietle propozycji zmian ustawowych, in: Dobre prawo - sprawne rządzenie, ed. B. Jaworska-Dębska, Łódź 2015.

Jendrośka J., Bar M., Nowe podejscie do polityki ekologicznej, Prawo i Środowisko 2014, No 3.

Jeżyńska B., Proekologiczne instrumenty wsparcia zrównoważonego rozwoju obszarów wiejskich, Studia Iuridica Agraria 2012, Vol. 12. 
Jurgilewicz M., Jurgilewicz O., Administracyjnoprawne zagadnienia ochrony powietrza, Warszawa 2014.

Kałuża D., Płoszka M., Robaszewska R., Wach P., Decyzje środowiskowe, Warszawa 2015.

Karciarz M., Kiełbus M., Dziatanie lub zaniechanie organu administracji publicznej jako przestanka wytaczajaca odpowiedzialnośc administracyjng na przyktadzie optaty podwyższonej za korzystanie ze srodowiska w orzecznictwie sqdów administracyjnych, Przegląd Prawa Ochrony Środowiska 2015, No 1.

Karpus K., Dostęp do wymiaru sprawiedliwości w partycypacji spotecznej w ochronie środowiska w świetle wyroku TS UE z dnia 15 stycznia 2013 r. w sprawie C-416/10 - komentarz, Przegląd Prawa Ochrony Środowiska 2014, No 4.

Karpus K., Pojęcie "»niedyskryminacyjnego ze względu na koszty" charakteru postępowań sqdowych" w świetle wyroku TS UE z dnia 13 lutego 2014 r. w sprawie C-530/11 - komentarz, Przegląd Prawa Ochrony Środowiska 2014, No 3.

Karpus K., Sprawozdanie z konferencji „Chronić chronione”, Torun dnia 12 sierpnia 2014 r., Przegląd Prawa Ochrony Środowiska 2014, No 3.

Karpus K., Sprawozdanie z ogólnopolskiej konferencji naukowej „Prawne aspekty gospodarowania zasobami środowiska" - Zjazd Katedr Prawa Ocbrony Środowiska, Toruń 15-16 maja 2014 r., Przegląd Prawa Ochrony Środowiska 2014, No 2.

Karpus K., The notion of 'Nature conservation body' in Polish Nature conservation law, its types and competences, Polish Yearbook of Environmental Law No 4 (2014).

Karpus K., Klimek G., MaciejewskaJ., Rakoczy B.(red.), Szalewska M., Tyburek M., Walas M., Prawo geologiczne i górnicze. Komentarz, Warszawa 2015.

Kaźmierska-PatrzycznaA., Kaźmierska-StępniakK., Rola systemuekozarządzania $i$ audytu EMAS w realizacji zrównoważonego rozwoju, Biatostockie Studia Prawnicze 2015, No 18.

Kaźmierska-Patrzyczna A., Król M. A., Przyrodnicze dobra chronione, in: Dobra chronione w prawie administracyjnym, ed. Z. Duniewska, Łódź 2014.

Kielin-Maziarz J., Rozporzqdzenie REACH w świetle zasady ostrożności, Przegląd Prawa Ochrony Środowiska 2014, No 2.

Kiełbus M., Akty prawa miejscowego w systemie gospodarowania odpadami komunalnymi - zagadnienia wybrane, Przegląd Prawa Ochrony Środowiska 2014, No 2.

Klimek G., Pieńczykowski M., Problematyka zaskarżania zarzq̨dzenia pokontrolnego organów Inspekcji Ochrony Środowiska, Przegląd Prawa Ochrony Środowiska 2014, No 2.

Knade-Plaskacz A., Dostęp do wymiaru sprawiedliwosci w sprawach dotyczacych srodowiska - transpozycja trzeciego filaru konwencji z Aarbus do prawa Unii Europejskiej, Przegląd Prawa Ochrony Środowiska 2014, No 1. 
Kolipiński B., Kilka uwag na temat systemowych uwarunkowań ochrony krajobrazu (z punktu widzenia kompetencji samorzqdu województwa), Samorząd Terytorialny 2014, No 12.

Korycki S., Podstawy prawne ochrony wód w Polsce, Państwo Prawne 2014, No 1.

Korzeniowski P., Bezpieczeństwo ekologiczne jako dobro prawnie chronione, in: Dobra chronione w prawie administracyjnym, ed. Z. Duniewska, Łódź 2014.

Korzeniowski P., Cele prewencyjne zarzadzania ryzykiem powodziowym w prawie ochrony środowiska, Przegląd Prawa Ochrony Środowiska 2014, No 4.

Korzeniowski P., Instrumenty prawne reglamentacji w gospodarce odpadami, Przegląd Prawa Ochrony Środowiska 2014, No 3.

Korzeniowski P., Koncepcja normatywna przeciwdziatania zanieczyszczeniom, Przegląd Prawa Ochrony Środowiska 2015, No 1.

Korzeniowski P., Obowiqzki prawne wynikajq̨e z hierarchii sposobów postępowania zodpadami, in: Dobre prawo-sprawne rzadzenie, ed. B. Jaworska-Dębska, Łódź 2015.

Korzeniowski P., O potrzebie koncepcji systemu prawa ocbrony środowiska, in: Dziesięć lat polskich doświadczeń w Unii Europejskiej. Problemy prawnoadministracyjne, vol. I, ed. J. Sługocki, Szczecin 2015.

Korzeniowski P., Pojęcie „srodowisko jako dobro wspólne" w systemie prawa ochrony środowiska, Zeszyty Naukowe Sądownictwa Administracyjnego 2015, No 1.

Korzeniowski P., Zasada rozszerzonej odpowiedzialności producenta w prawie gospodarki odpadami, Acta Universitatis Lodziensis. Folia Iuridica 2015, № 74.

Korzeniowski P., Zezwolenia na zbieranie i przetwarzanie odpadów oraz pozwolenie na wytwarzanie odpadów, Prawo i Środowisko 2014, No 2.

Kosieradzka-Federczyk A., Glosa do wyroku Naczelnego Sadu Administracyjnego z 18 IV 2014, II OSK2769/12, Gdańskie Studia Prawnicze. Przegląd Orzecznictwa 2014, No 3.

Kosieradzka-Federczyk A., Powszechne obowiqzki dotyczace środowiska w świetle wybranych regulacji konstytucyjnych, in: Dobra publiczne w administracji, eds. M. Woźniak, E. Pierzchała, Opole 2014.

Kosior W., Wybrane zagadnienia prawa energetycznego w świetle orzecznictwa Trybunatu Konstytucyjnego, Zeszyty Naukowe Uniwersytetu Warszawskiego. Prawo 2014, No 14.

Kropiewnicka M., Czech M., Ostrowiecki D., Reklama częścia krajobrazu - nowe regulacje prawne dotyczace reklamy zewnętrznej w świetle prezydenckiego projektu ustawy o zmianie niektórych ustaw w zwiqzzu ze wzmocnieniem narzędzi ochrony krajobrazu, Przegląd Prawa Ochrony Środowiska 2014, No 2.

Król M.A., Dekada prawnej ochrony biosfery w dziatalności rolniczej, in: Dziesięć lat polskich doświadczeń w Unii Europejskiej. Problemy prawnoadministracyjne, vol. I, ed. J. Sługocki, Szczecin 2015. 
Król M. A., Producent rolny jako podmiot korzystający ze środowiska, Studia Iuridica Agraria 2013, vol. 11.

Krupa B., Udziat organizacji ekologicznych w postepowaniu administracyjnym o wydanie decyzji o środowiskowych uwarunkowaniach realizacji przedsięwzięcia, Ius et Administratio 2014, No 3.

Krupa B., Zasady odpowiedzialności za szkodę w środowisku - aspekty administracyjnoprawne, Orzecznictwo Sądowe w Sprawach Gospodarczych 2015, No 2.

Kubas E., Kuśnierz-Chmiel J., Woda jako dobro wspólne, in: Dobra chronione w prawie administracyjnym, ed. Z. Duniewska, Łódź 2014.

Kudrzycka A., Postępowanie administracyjne w sprawie wymierzenia administracyjnej kary pieniężnej, Przegląd Prawa Ochrony Środowiska 2014, No 2.

Kuraś B., Wałkowski D., Zielińska-Barłożek I., Prawo ochrony środowiska w transakcjach fuzji i przejęć oraz nabycia nieruchomości, Warszawa 2014.

Lipiński A., Niektóre problemy planowania przestrzennego w zwiqzku z dziatalnościq regulowanq prawem geologicznym i górniczym, Studia Iuridica Agraria 2012, Vol. 12.

Lipiński A., Niektóre problemy solidaryzmu w prawie ochrony środowiska, in: Idea solidaryzmu we wspótczesnym prawie konstytucyjnym: doświadczenia polskie $i$ międzynarodowe, ed. A. Łabno, Warszawa 2015.

Lipiński A., Nowela weglowodorowa (ustawa z dnia 11 lipca 2014 r. o zmianie ustawy Prawo geologiczne i górnicze oraz niektórych innych ustaw) a niektóre problemy zagospodarowania przestrzennego, Casus 2015, No 76.

Lipska-Sondecka A., Badowska-Domagała E., Ustawa o utrzymaniu czystości i porzadku w gminach a administracja samorzq̨dowa, Prawo i Środowisko 2015, No 2.

Łapecki F., Aspekty środowiskowe w zamówieniach publicznych, Prawo Zamówień Publicznych 2015, No 1.

Majkowska-Szulc S., Odpowiedzialnośc podmiotów gospodarczych za szkodę wyrzadzonq śodowisku naturalnemu z perspektywy pierwszych 10 lat cztonkostwa Polski w Unii Europejskiej, Gdańskie Studia Prawnicze 2015, No 33.

Makowski M., Budowa pierwszej Polskiej elektrowni jądrowej a ochrona środowiska Morza Battyckiego w świetle prawa międzynarodowego, Prawo Morskie 2014, No 30.

Malinowski D. M., Problematyka podmiotowości prawnej zwierzqt na przyktadzie koncepcji utylitaryzmu Petera Singera, Przegląd Prawa Ochrony Środowiska 2014, No 2.

Marszelewski M., Gospodarowanie odpadami medycznymi i weterynaryjnymi w ustawie o odpadach, Przegląd Prawa Ochrony Środowiska 2014, No 2.

Marszelewski M., Marszelewski W., Jezioro Radodzierz-przyktad wykluczających sięrodzajów wtasności, Przegląd Prawa Ochrony Środowiska 2014, No 1. 
Marszelewski M.,MarszelewskiW.,Prawo powszechnego dostępu do wód publicznych i problemy z jego wykonywaniem ze szczególnym uwzględnieniem jezior, Przegląd Prawa Ochrony Środowiska 2014, No 4.

Matuszczak M., Prawo wtasności odpadów komunalnych, Ruch Prawniczy, Ekonomiczny i Socjologiczny 2014, No 3.

Medvedieva M., Konfrontacyjne $i$ niekonfrontacyjne środki implementacji międzynarodowego prawa ocbrony środowiska, Przegląd Prawa Ochrony Środowiska 2014, No 2.

Micińska-Bojarek M., Legalność polowań na ptaki towne (Opinia prawna), Prawo i Środowisko 2014, No 3.

Micińska-Bojarek M., Eowiectwo. Aspekt bumanitarno-prawny, Poznań 2014.

Micińska-Bojarek M., Obszary klęski ekologicznej Federacji Rosyjskiej - status prawny i programy naprawcze, Prawo i Środowisko 2014, No 4.

Mikosz R., Plan zagospodarowania przestrzennego terenu górniczego, Studia Iuridica Agraria 2012, Vol. 12.

Modrzejewski A. K., Środowisko dobrem chronionym przez „zainteresowanq spotecznośc" w gospodarowaniu odpadami wydobywczymi, in: Dobra chronione w prawie administracyjnym, ed. Z. Duniewska, Łódź 2014.

Możdżyń O., Lepsza jakość powietrza i ochrona przed hatasem, Prawo i Środowisko 2015, No 2.

Niczyporuk J., Regulacja kompetencji administracji leśnej, Białostockie Studia Prawnicze 2015, No 18.

Nieć A., Prawne aspekty prowadzenia drogowego transportu odpadów, Przegląd Prawa Ochrony Srodowiska 2014, No 2.

Niewiadomski A., Problematyka prawna rekompensat za ustanowienie formy ochrony przyrody - obszarów Natura 2000 na obszarach wiejskich, Studia Iuridica Agraria 2014, Vol. 12.

Nowak M. J., Decyzja o warunkach zabudowy i decyzja środowiskowa, Warszawa 2015.

Nowak M.J., Decyzje o środowiskowych uwwarunkowaniach a inne akty administracyjne, Nieruchomości 2015, No 4.

Nowak M.J., Wycinanie drzew - kluczowe problemy, Wspólnota 2014, No 3.

Paczuski R., Ochrona zasobów leczniczych środowiska Rzeczypospolitej Polskiej jako jedna z podstawowych form zarzadzania ochronq środowiska przy respektowaniu zasady zrównoważonego rozwoju, Białostockie Studia Prawnicze 2015, No 18.

Pasternak T., Zwalczanie przestępstw i wykroczeń leśnych. Wybrane procedury, Warszawa 2014.

Pawłowska K., Udziat spoteczeństwa wochronie i ksztattowaniu krajobrazu, Samorząd Terytorialny 2012, No 12.

Pązik A., Słomski M., Prawo towieckie. Komentarz, Warszawa 2015. 
Pływaczewski W., Degradacja krajobrazu jako szczególna forma wandalizmu ekologicznego - kontrowersje wokót lokalizacji farm wiatrowych na obszarach wyróżniających sie cennymi walorami naturalnymi i kulturowymi, in: Wandalizm wobec dziedzictwa naturalnego i kulturowego, eds. Pływaczewski, S. Buczyński, Olsztyn 2015.

Prawna regulacja geologii $i$ górnictwa w Polsce, Czechach i na Stowacji. Wybrane zagadnienia, eds. G. Dobrowolski, G. Radecki, Katowice 2014.

Prawne aspekty gospodarowania zasobami środowiska. Korzystanie z zasobów środowiska, eds. B. Rakoczy, M. Szalewska, K. Karpus, Toruń 2014.

Prawne aspekty gospodarowania zasobami środowiska. Oddziatywanie na zasoby środowiska, eds. B. Rakoczy, M. Szalewska, K. Karpus, Toruń 2014.

Prawo ochrony środowiska w transakcjach fuzji i przejęć oraz nabycia nieruchomości, eds. D. Wałkowski, I. Zielińska-Barłożek,Warszawa 2014.

Raczyńska W., Konwencja z Aarhus-sktadanie przezspoteczeństwo uwag i wniosków, Prawo i Środowisko 2015, No 2.

Raczyńska W., Konwencja z Aarhus w praktyce, Prawo i Środowisko 2015, No 1.

Raczyńska W., Odpady niebezpieczne w prawie ukraińskim (Zgodność statusu prawnego z konwencja bazylejskq i dyrektywa 2008/98/WE), Prawo i Środowisko 2014, No 3.

Raczyńska W., Podstawy budowy administracji ocbrony środowiska, Prawo i Środowisko 2014, No 2.

Raczyńska W., Ramy czasowe i miejsce procedury udziatu spoteczeństwa w procesie decyzyjnym, Prawo i Środowisko 2014, No 4.

Radecki W., Kompendium prawa rybackiego, Poznań 2014.

Radecki W., Nauka prawa ochrony środowiska w Polsce, Przegląd Prawa Ochrony Środowiska 2014, No 4.

Radecki W., Odpowiedzialność w prawie środowiska, Prawo i Środowisko 2014, No 2.

Radecki W., Parki narodowe w systemach prawnych ochrony przyrody polskim, czeskim i stowackim, Ius Novum 2014, No 4.

Radecki W., Parki narodowe w systemach prawnych ochrony przyrody polskim, czeskim i stowackim. Cz. 2, Ius Novum 2015, No 1.

Radecki W., Prawna ochrona przyrody w Polsce a Natura 2000, leśnictwo, towiectwo i rybactwo, Warszawa 2014.

Radecki W., Recenzja: Odpovédnost v pravu životniho prostředi - současny stav a perpektivy (Brno 2013), Prawo i Środowisko 2015, No 1.

Radecki W., Ustawy o ochronie zwierząt. Komentarz, Warszawa 2015.

Radecki W., Danecka D., Czeskie przepisy o ochronie drzew i krzewoów z perspektywy oczekiwanej nowelizacji przepisów polskich. Cz. 1. Zagadnienia administracyjne, Casus 2015, No 76. 
Radecki W., Danecka D., Czeskie przepisy o ochronie drzew i krzerwów z perspektywy oczekiwanej nowelizacji przepisów polskich. Cz. 2. Zagadnienia odpowiedzialności prawnej, Casus 2015, No 77.

Radecki W., Rotko J., Podstawowe cechy czeskiego prawa wodnego z polskiej perspektywy, Przegląd Prawa Ochrony Środowiska 2014, No 1.

Radziwon I., Natura 2000 jako dziatanie na rzecz zrównoważonego rozwoju, Białostockie Studia Prawnicze 2015, No 18.

Rakoczy B., Nabycie wtasności gruntu pokrytego wodami, Przegląd Prawa Ochrony Środowiska 2015, No 1.

Rakoczy B., Organisation of municipal waste management in Polish law, Polish Yearbook of Environmental Law No 4 (2014).

Rakoczy B., Prawo wtasności gruntów pod wodami, Przegląd Prawa Ochrony Środowiska 2014, No 1.

Rakoczy B., Problematyka przytacza kanalizacyjnego w orzecznictwie Sqdu Najwyższego, Bydgoszcz 2014.

Rakoczy B., Recenzja: J. Stelmasiak, Interes indywidualny a interes publiczny w ochronie środowiska w obszarze specjalnym o charakterze ekologicznym (Rzeszórw 2013), Przegląd Prawa Ochrony Srodowiska 2014, No 2.

Rakoczy B., Stec R., Woźniak A., Prawo towieckie. Komentarz, Warszawa 2014.

Rakoczy B., Wierzbowski B., Prawo ochrony środowiska. Zagadnienia podstawowe, Warszawa 2015.

Rosik-Dulewska C., Podstawy gospodarki odpadami, Warszawa 2015.

Rotko J., Recenzja: A. Habuda, Obszary Natura 2000 w prawie polskim (Warszawa 2013), Przegląd Prawa Ochrony Środowiska 2014, No 1.

Rotko J., Wtasnośc $i$ zarzad urzadzeniami wodnymi w orzecznictwie sq̨ów administracyjnych, Studia Prawnicze 2014, No 3.

Różowicz K., Aspekty ekoinnowacyjne jako kryterium oceny ofert w prawie zamówień publicznych, Przegląd Prawa Ochrony Środowiska 2014, No 3.

Różowicz K., Ustrojowe podstawy realizacji polityki zielonych zamórwień publicznych, Przegląd Prawa Ochrony Środowiska 2015, No 1.

Schiano di Pepe L. Szuma K., Recenzja: Lineamenti di diritto ambientale polacco, a cura di Karolina Szuma, contributi di Bartosz Rakoczy, Jan Szuma, ed. Aracne, 2013, Przegląd Prawa Ochrony Środowiska 2014, No 3.

Sikorski S., Rola i organizacja Narodowego oraz wojewódzkich funduszy ochrony środowiska i gospodarki wodnej, Białostockie Studia Prawnicze 2015, No 18.

Skorupińska A., Zabezpieczenie roszczeń w polskim prawie ochrony środowiska, Studia Prawnicze 2014, No 2.

Skóra A., Recenzja: M. Micińska-Bojarek, Eowiectwo. Aspekt humanitarno-prawny (Poznañ 2014), Przegląd Prawa Ochrony Środowiska 2014, No 1.

Skrzyp J., Bezpieczeństwo ekologiczne w ujęciu administracyjno-prawnym, in: Ksiega jubileuszowa z okazji dziesięciolecia funkcjonowania Instytutu Administracji, 
Samorzqdu i Prawa Uniwersytetu Przyrodniczo-Humanistycznego w Siedlcach, eds. D. Strus, A. Duk-Majewska, Warszawa, Siedlce 2014.

Staniewska A., Potrzeba ochrony, zarzqdzania krajobrazem $i$ racjonalnego ksztattowania krajobrazu w odniesieniu do Europejskiej Konwencji Krajobrazowej $i$ prezydenckiego projektu tzw. ustawy krajobrazowej, Samorząd Terytorialny 2014, No 12.

Stec R., Straże w stużbie ochrony przyrody. Straż leśna, towiecka, rybacka i parków narodowych. Pozycja ustrojowa oraz miejsce w systemie organizacyjno-prawnym bezpieczeństwa i porzadku publicznego, Warszawa 2014.

Stankiewicz R., Znaczenie aktów planowania w prawie ochrony środowiska, in: Źródta prawa administracyjnego a ochrona wolności i praw obywateli, eds. M. Błachucki, T. Górzyńska, Warszawa 2014.

Stańko M., Ochrona gruntów rolnych na obszarach realizacji inwestycji przeciwpowodziowych - wybrane zagadnienia prawne, Studia Iuridica 2014, No 59.

Stelmaszczyk Ł., Realizacja inwestycji infrastrukturalnych celu publicznego na terenach zieleni, Przegląd Prawa Ochrony Środowiska 2015, No 1.

StochlakJ., Recenzja: W. Radecki - Prawna ochrona przyrody w Polsce a Natura 2000, leśnictwo, towiectwo i rybactwo (Warszawa 2014), Prawo i Środowisko 2015, No 4.

StochlakJ., Środowiskowe ustawy harmonizujące w polskim prawie ochrony środowiska w latach 2000-2014, Prawo i Środowisko 2014, No 3.

Strus D., Wspótdziatanie jednostek samorzqdu terytorialnego z organizacjami pozarzadowymi w procesie kreowania polityki publicznej w ochronie środowiska, in: Partnerstwa w sferze publicznej, eds. A. Kołomycew, B. Kotarba, Warszawa 2014.

Symonides E., Ochrona przyrody, Warszawa 2014.

Szalewska M., Glosa do wyroku Naczelnego Sadu Administracyjnego z 13 II 2014 r., II OSK 2093/12, Przegląd Prawa Ochrony Środowiska 2014, No 4.

Szalewska M., Glosa do wyroku Naczelnego Sadu Administracyjnego z 17 V 2013, II FSK 1833/12, Przegląd Prawa Ochrony Środowiska 2014, No 1.

Szalewska M., Glosa do wyroku Sqqu Najwyższego z 4 XII 2013, II CSK 161/13, Przegląd Prawa Ochrony Środowiska 2014, No 2.

Szalewska M., Glosa do wyroku Wojewódzkiego Sqadu Administracyjnego w Biatymstoku z dnia 27 lutego 2014 r., II SA/Bk 702/13, Przegląd Prawa Ochrony Środowiska 2014, No 3.

Szalewska M., Nadzór nad dziatalnościq spótki wodnej, Przegląd Prawa Ochrony Środowiska 2015, No 1.

Szalewska M., Permit for exceptions to probibitions introduced to protect species of plants, animals and fungi, Polish Yearbook of Environmental Law No 4 (2014). 


\section{Martyna Walas}

Sześciło D., O (nie)racjonalnym ustawodawcy na przyktadzie regulacji tworzenia i zmiany granic parków narodowych, Przegląd Prawa Ochrony Srodowiska 2014, No 4.

Szuma K., Glosa do postanowienia Naczelnego Sadu Administracyjnego z dnia 21 stycznia 2014 r. II OW 127/13, Przegląd Prawa Ochrony Środowiska 2014, No 4.

Szuma K., Glosa do wyroku Wojewódzkiego Sąu Administracyjnego w Krakowie z dnia 3 grudnia 2013 r., II SA/Kr 1098/13, Przegląd Prawa Ochrony Środowiska 2014, No 3.

Szuma K., The imposition of an increased environmental fee for operating without a required permit or another administrative decision, and the cause of the absence of the permit or decision, Polish Yearbook of Environmental Law No 4 (2014).

Szwejkowska M., Truszkowski W., Prawo do środowiska a narastająe zagrożenia ekologiczne, Studia Prawnoustrojowe 2014, Vol. 25.

Szydło W., Zakres wtadzy dyskrecjonalnej $i$ wspótdziatania organów samorzq̨du terytorialnego przy udzielaniu koncesji geologicznych i górniczych, Samorząd Terytorialny 2014, No 11.

Śleszyński P., Gtos w dyskusji w sprawie „ustawy krajobrazowej”, Samorząd Terytorialny 2014, No 12.

Śliwa J., Raport oddziatywania na środowisko jako dowód w postępowaniu w sprawie oceny oddziatywania na środowisko, Samorząd Terytorialny 2015, No 9.

Świderski K., Zmiana lasu na użytek rolny, Casus 2014, No 74.

Tarnowska A., Rozwiqzania instytucjonalne w zakresie ochrony przyrody w II RP, Przegląd Prawa Ochrony Środowiska 2014, No 4.

Trzcińska D., Administracyjnoprawne instrumenty ochrony przyrody po akcesji Polski do Unii Europejskiej, in: Dziesięć lat polskich doświadczeń w Unii Europejskiej. Problemy prawnoadministracyjne, vol. I, ed. J. Sługocki, Szczecin 2015.

Trzcińska D., Wtaściwość rzeczowa regionalnego dyrektora ocbrony środowiska, in: Organizacja administracji publicznej z perspektywy powierzanych jej zadan, ed. T. Bąkowski, Warszawa 2015.

Trzewik J., Koncepcja teoretyczna prawa do środowiska w ujęciu publicznoprawnym, in: Dziesięć lat polskich dośrwiadczeń w Unii Europejskiej. Problemy prawnoadministracyjne, vol. I, ed. J. Sługocki, Szczecin 2015.

Trzewik J., Wybrane zagadnienia wykorzystania instytucji praw podmiotowych w prawie ochrony środowiska, in: Samorzad terytorialny z punktu widzenia nowoczesnej administracji: księga poświęcona pamięci Jacka Dziobka-Romańskiego, ed. S. Wrzosek, M. Pyter, M. Ganczar, Lublin 2014.

TrzewikJ., Z problematyki przenoszenia praw i obowiązków z pozwoleń na korzystanie ze środowiska, Przegląd Prawa Ochrony Środowiska 2015, No 1. 
Tyrawa D., Bezpieczeństwo ekologiczne państwa w dziataniu administracji publicznej w Polsce. Wybrane problemy, in: Bezpieczeństwo narodowe Rzeczypospolitej Polskiej: wybrane zagadnienia prawne, eds. M. Karpiuk, K. Orzeszyna, Warszawa 2014.

Walas M., Polish Legal Bibliography of Environmental Law, Polish Yearbook of Environmental Law No 4 (2014).

Walas M., Sprawozdanie z IV Konferencji Sieci Zrównoważonego Rozwoju „Zasada zrównoważonego rozwoju w wymiarze gospodarczym i ekonomicznym" Toruń, 25 listopada 2014 roku, Przegląd Prawa Ochrony Środowiska 2014, No 4.

Walczak M., Doświadczenia na zwierzętach w świetle prawa unijnego a perspektywy polskie, Przegląd Prawa Publicznego 2014, No 12.

Werbel-Cieślak M., Rola przepisów o odpowiedzialności podmiotów zbiorowych za czyny zabronione pod groźbq kary w polskim systemie prawnej ochrony środowiska, Warszawa 2014.

Wilbrandt-Gotowicz M., Regulacja prawna wprowadzania do obrotu produktów biobójczych w świetle rozporządzenia Parlamentu Europejskiego $i$ Rady nr 528/2012 - wybrane zagadnienia, Przegląd Prawa Ochrony Środowiska 2014, No 4.

Wilk-Ilewicz A., Decyzja o środowiskowych uwarunkowaniach realizacji przedsięwzięcia wedtug wymogów prawa Unii Europejskiej, Zeszyty Naukowe Sądownictwa Administracyjnego 2015, No 4.

Wlaźlak K., Funkcja planowania gminy na przyktadzie programu opieki nad zwierzętami bezdomnymi oraz zapobiegania bezdomności zwierząt, Przegląd Prawa Publicznego 2015, No 4.

Woźniak M., Naruszenie dóbr osobistych hatasem, Przegląd Sądowy 2015, № 6.

Woźniak M., Prawna koncepcja ochrony krajobrazu jako dobra publicznego, in: Dobra publiczne w administracji, eds. M. Woźniak, E. Pierzchała, Opole 2014.

Wójcik-Jackowski S., Wody opadowe i ich odprowadzanie, Przegląd Prawa Ochrony Środowiska 2014, No 1.

Zacharzewski K., Skutki nielicencjonowanego pośrednictwa w obrocie uprawnieniami do emisji CO2 do atmosfery (EUA) w realiach dyrektywy MiFID 2 z 2014 roku, Przegląd Prawa Ochrony Środowiska 2015, No 1.

Zakrzewska M., Zadania regionalnego dyrektora ochrony środowiska w zakresie zaperwnienia udziatu spoteczeñstwa w procedurze oceny oddziatywania przedsięrwzięcia na środowisko w świetle zasady subsydiarności, in: Organizacja administracji publicznej z perspektywy powierzanych jej zadań, ed. T. Bąkowski, Warszawa 2015.

Zasada zrównoważonego rozwoju w wymiarze gospodarczym i ekonomicznym, eds. B. Rakoczy, K. Karpus, M. Szalewska, M. Walas, Toruń 2015.

Zębek E.M., Raczkowski M., Prawne i techniczne aspekty gospodarowania odpadami komunalnymi, Przegląd Prawa Ochrony Środowiska 2014, No 3. 


\section{Martyna Walas}

Zgoła P. M., Sprawozdanie z międzynarodowej konferencji naukowej „International environmental law: contemporary concerns and challenges in 2014", 5-6 czerwca 2014 roku, Ljubljana, Przegląd Prawa Ochrony Środowiska 2014, No 2.

Zielińska P., Administracyjna kara pieniężna za usuwanie drzerw lub krzerwów bez zezwolenia - charakter odpowiedzialności, Przegląd Prawa Ochrony Środowiska 2015, No 1.

Ziemblicki M. H., Uwarunkowania prawne nadzoru nad lasami niestanowiacymi wtasności Skarbu Państwa, Białostockie Studia Prawnicze 2015, No 18.

\section{Email}

martyna.walas@gmail.com 